review to which one or two supplementary reviews may be added. Reprints of these papers will be sent to the members of the Congress at their home addresses, or-at the very latest-will be handed over to the members at the opening sessions of the Congress. Copies of the individual papers are likewise to be distributed before the sessions, the main object of this Congress being the discussion of cytological topics of special interest. The following subjects have been chosen for review : epithelium in culture and in the organism; structure of chromosomes; mechanism of mitosis ; cancer cells and normal cells ; experimental research on cytology and viruses; ultra-structure of the protoplasm and its products; chemistry of the cell. Further information can be obtained from the honorary secretary for the Congress, Dr. Harald Okkels, Institute for Pathological Anatomy, University of Copenhagen, Denmark.

\section{Congress of Anthropological and Ethnological Sciences}

FURTHER arrangements are announced for the second International Congress of Anthropological and Ethnological Sciences, which will be held in Copenhagen on August 1-6, 1938 (see Nature, July 24, 1937, p. 147). This date has been chosen to meet the convenience of any members who may also attend the International Congress of Geography at Amsterdam on July 18-28. The proceedings at Copenhagen will take place in both general and sectional meetings. There will be eight sections, and a number of subsections, each being devoted to some one branch of anthropological study with a special topic proposed for discussion, though this does not preclude the acceptance of communications dealing with other matters. Among the topics proposed, the following may be mentioned: under Physical Anthropology, in the subsection of Anatomy and Biotypology, meeting under Prof. H. M. Houdensen-interrelation of types of fossil man, methodology, and the conception of 'race' in anthropology ; Subsection of Physiological Anthropology, under Prof. Oluf Thomsen, geographical distribution of blood groups in man and their presence in animals; in the Section of Psychology, under Prof. Edgar Rubin, influence of the factors of civilization on character and (with the Section of Sociology and Religion) on cultural changes; in the Section of Ethnology, under Prof. Gudmund Hart, origins of agriculture and the domestication of animals and plants; in the Section of Ethnography, in the subsections of Asia and Africa, of which M. C. G. Feilberg, curator of the Ethnographical Museum and M. Carl Kjersmeier are the respective presidents, the nomad pastorals of Asia and Africa; in the subsection of Arctic Ethnography, under Dr. Therkel Mathiassen, the prehistoric and historic culture-movements of the circumpolar region; and in the Section of Sociology and Religion under Prof. Wilh. Gronbech, the extent to which archæology and prehistory can serve as a basis for the study of intellectual development. Applications for membership should be addressed to the Treasurer of the Congress, Nationalmuseet, $10 \mathrm{Ny}$ Vestergade, Copenhagen, $\mathbf{K}$.

\section{National Parks of the Belgian Congo}

The Institute of the National Parks of the Belgian Congo, Brussels, has decided to publish a collection of photographs of the vegetation of these parks, and has commenced by issuing a very fine series of photographs of the general aspect of the vegetation of the Albert National Park, which comprises some 900,000 hectares in the heart of tropical Africa to the north of Ruwenzori and including several volcanoes. The photographs, taken during the expedition of G. F. de Witte (1933-35), are excellent, and they are beautifully reproduced in the first number of this new production (Vol. 1, Fascicules 1 and 2, Plates 1-12, Brussels, 1937) : they include some striking examples of arborescent species of Senecio and giant Lobelia.

\section{Announcements}

Prof. James P. Kendall, professor of chemistry in the University of Edinburgh, has given 1,000 dollars to the American Chemical Society for the 1938 American Chemical Society award in pure chemistry. The award, established in 1931 by A. C. Langmuir to encourage creative work in pure chemistry by men of science at the beginning of their careers, will be made for 1938 at the Society's spring meeting in Dallas, Tex., on April 18-21. The age limit, hitherto thirty, has been raised to thirty-five years. Prof. Kendall was professor at Columbia University from 1913 until 1926, and afterwards head of the department of chemistry at Washington Square College, New York University.

A series of two popular lectures by Prof. C. E. Inglis, entitled "Building Big Bridges", has been arranged by the Engineering Public Relations Committee, primarily for those between the ages of 15 and 20 years. The lectures will be given on January 7 and 10 at 3 p.m., at the Institution of Electrical Engineers, Savoy Place, Victoria Embankment, W.C.2. Application for tickets, which are free, should be made to the Public Relations Officer, Engineering Public Relations Committee, 1-7 Great George Street, Westminster, S.W.1.

DR. B. L. Bhatia, formerly assistant professor of zoology at the Government College, Lahore, and later principal of the Government College, Hoshiarpur, and author of works on Ciliophora and Sporozoa in the Fauna of British India series, has established "The Science Press of India" as a science news agency for the daily Press in that country. His address is Hotusingh Road, Lahore.

Catalogue 15 B (II) of laboratory balances, issued by Griffin and Tatlock, Ltd., contains particulars of a wide range of analytical balances (ordinary, aperiodic, projection-reading, chainomatic) and a noteworthy selection of micro-analytical balances. The catalogue also includes weights, scales and spring balances. A very cheap silica-gel desiccator to replace calcium chloride in balance cases, which lasts indefinitely, is listed. 